\title{
Sustainable
}

Jurnal Kajian Mutu Pendidikan

LPM IAIN Syaikh Abdurrahman Siddik Bangka Belitung

https://jurnal.Ip2msasbabel.ac.id/index.php/sus ISSN 2655-0695 (Online)

\section{Bahaya Perekrutan Terorisme Melalui Media Sosial Di Indonesia}

\author{
Irawan dan Nasrun
}

IAIN Syaikh Abdurrahman Siddik Bangka Belitung

Keyword:

Terorisme

Sosial media

Psikologi

Kata Kunci:

Terrorism

social media

psychology

\begin{abstract}
Terrorism threats human life. The impact of acts of terrorism can eliminate human lives, be injured, and psychological trauma. Therefore, acts of terrorism and the spreadof terrorism must be eradicated. This paper aims to explain the dangers of recruiting terrorism through social media and the strategic steps to prevent it. The recruitment of terrorism through social media is very dangerous because it affects the psychology of society. Social media should be used for useful purposes, not to influence the other people to become potential terrorists. Likewise, Islam teaches its adherents to practice friendly Islam. The method used in this paper is qualitative analysis. The approach used is the psychology of the terrorist Red A. Hudson. This paper concludes that acts of terrorism creat fear, anxiety, and are against with Islam rah\{matan li a>lami>n, Pancasila, UUD 1945, Negara Kesatuan Republik Indonesia, dan Bhinneka Tunggal Ika. Efforts to prevent the recruitment of terrorists through social media are guidance to the public about the dangers of terrorism by the government (Misnistry of Communication and Information of the Republic of Indonesia), religious leaders and community leaders.
\end{abstract}

\section{Abstrak}

Terorisme mengancam kehidupan manusia. Dampak aksi terorisme dapat menghilangkan nyawa manusia, terluka, dan trauma psikologis. Oleh karena itu, aksi terorisme dan penyebaran paham terorisme harus dibasmi. Tulisan ini bertujuan untuk menjelaskan bahaya perekrutan terorisme melalui media sosial dan langkah-langkah strategis pencegahannya. Perekrutan terorisme melalui media sosial sangat berbahaya karena mempengaruhi psikologi masyarakat. Media sosial seharusnya digunakan untuk kepentingan yang bermanfaat, bukan untuk mempengaruhi orang lain menjadi calon teroris. Demikian juga Islam mengajarkan bagipenganutnya agar memprakkan Islam yang ramah.Metode yang digunakan dalam tulisan ini adalah analis kualitatif. Adapun pendekatan yang digunakan adalah pendekatan psikologi teroris (the psychology of the Terrorist) Rex A. Hudson. Tulisan ini menyimpulkan bahwa tindakan terorisme memberikan rasa takut, cemas, dan bertentangan dengan Islam rahmatan li a'lamin, Pancasila, UUD 1945, Negara Kesatuan Republik Indonesia, dan Bhinneka Tunggal Ika. Langkah-langkah pencegahan perekrutan teroris melalui media sosial adalah pembinaan kepada masyarakat tentang bahaya terorisme oleh pemerintah (Kementerian Komunikasi dan Informasi Republik Indonesia), tokoh agama, dan tokoh masyarakat. 


\section{Pendahuluan}

Terorisme apapun alasannya tidak dibenarkan oleh agama dan negara Indonesia. Data-data aksi terorisme dapat diidentifikasikan antara lain: Bom Bali I (12 Oktober 2002), ${ }^{1}$ bom JW Marriott (otak pelakunya Noordin M. Top dan Dr. Azahari, 5 Agustus 2003), ${ }^{2}$ teror skala kecil di Poso (2003), pengeboman Kedutaan Australia (otak pelakunya Noordin M. Top dan Dr. Azahari Husin, 2004), Bom Bali II (otak pelakunya Noordin M. Top dan Dr. Azahari Husin, 1 Oktober 2005), ${ }^{3}$ pengeboman Marriott dan Ritz-Carlton (otak pelakunya Noordin M. Top dan Dr. Azahari Husin 2009), pengeboman di Starbucks yang berafiliasi dengan ISIS (2016). ${ }^{4}$

Serangan bom tiga gereja di Surabaya (13 Mei 2018), 5 dan serangan yang masih ada hubungannya dengan terorisme, yaitu kerusuhan terjadi di antara para narapidana teroris di Lembaga Pemasyarakatan Mako Brimob Kelapa Dua, Depok, Jawa Barat (pada Selasa Malam 8 Mei 2018 hingga Rabu, 9 Mei 2018 dini hari). ${ }^{6}$ Selanjutnya, serangan teroris ke markas Kepolisian Daerah Riau menyebabkan 1 anggota polisi tewas dan 4 teroris ditembak mati (16 Mei 2018). ${ }^{7}$

Tindakan teorisme disebabkan beberapa faktor, sebagaimana dijelaskan James Lutz dan Brenda Lutz, yaitu: faktor politis, ideologis dan etnis, ekonomi, dan psikologis. Dalam melakukan aksinya, teroris melakukan strategi:memberikan rasa simpati, intimidasi, provokasi, merampok, menghardik, ${ }^{8}$ melakukan bom bunuh diri, ${ }^{9}$ dan radikalisasi atau militansi. ${ }^{10}$ Seiring perjalanan waktu, kelompok teroris merubah strategi atau mengkombinasikan strategi yang telah ada dengan strategi baru. Sedangkan pengkaderan dalam struktur terorisme - terutama Jamaah Islamiyah (JI) - terdiri dari empat tahapan: tabligh (ceramah

${ }^{1}$ Pada peristiwa "Bom Bali I" ini terjadi tiga kali ledakan: 1. Di Paddy's Irish Bar 2. Di luar the Sari Club 3.Bom diledakkan di dekat konsulat Amerika Serikat di Bali, namun tidak menyebabkan cidera atau kematian. Mayoritas korban meninggal dunia pada Bom Bali I ini adalah orang asing: Australia (80 orang), Inggris (26 orang), dan Indonesia (35 orang). Rodney P. Carlisle, ed., One Day in History: September 11, 2001 (New York: HarperCollins, 2007), 17.

${ }^{2}$ Pada peristiwa ini terdapat 11 orang meninggal dunia.Putu Setia, "Mariot II", dalam, Cari Angin 2: Kumpulan Esai di Koran Tempo Minggu 2009-2012, Putu Setia dan Toriq Hadad (Jakarta: TEMPO Publishing, 2013).

${ }^{3}$ Setelah perekonomian Bali kembali bangkit, bom ternyata meledak lagi di Bali pada 1 Oktober 2005, yang dikenal dengan "Bom Bali II".Ledakan "Bom Bali II" (nampaknya dilakukan oleh Jamaah Islamiyah juga) ini membuat Bali tambah terpuruk, karena belum pulih benar dari "Bom Bali I" sudah dihancurkan oleh bom yang kedua. Putu Setia, Mendebat Bali: Catatan Perjalanan Budaya Bali hingga Bom Kuta (Denpasar: PT Pustaka Manikgeni, 2012).

${ }^{4}$ Julie Chernov Hwang, Why Terrorists Quit: The Disengagement of Indonesian Jihadists (Ithaca and London: Cornell University Press, 2018), xxi.

${ }^{5}$ Dalam insiden ini, satu keluarga yang terdiri dari 6 orang - termasuk anak perempuan berusia 9 tahun dan 12 tahun nampaknya baru pulang dari Syria. Dalam serangan itu, ayah dari keluarga tersebut menggunakan sebuah mobil dengan muatan bom, anak-anak putranya mengendarai motor sambil membawa bom, sementara istri dan dua anak perempuannya meledakkan bom di tiga gereja secara terpisah. Sedikitnya 13 orang tewas. Lihat "Indonesia Social Media Slams Use of Children in Church Bombings", BBC Monitoring Asia Pacific, London, 14 May 2018.

${ }^{6}$ Insiden itu menyebabkan lima polisi dan seorang narapidana tewas. Lihat "Indonesia: Indonesia will not Flinch in War against Terrorism - Jokowi”, Asia News Monitor, Bangkok, 14 May 2018.

${ }^{7}$ Deadly Terrorist Attack on Indonesia Police Headquarters, Iran Daily; Tehran, 16 May 2018.

${ }^{8}$ A. H. Kydd and Walter B. F., "The Strategies of Terrorism," International Organization, 31, 1 (2006): 49-80.

${ }^{9}$ Dalam keyakinan Imam Samudra, tindakan bom bunuh diri yang dilakukannya dibenarkan oleh hadis dan ayat alQur'an. Imam Samudra merujuk pada kitab karya Ibn Nuhas yang memuat 16 hadis tentang aksi beberapa orang yang menyerang musuh tanpa menghiraukan keselamatan dirinya. Tindakan bom bunuh diri ini relevan dengan ayat Al-Qur'an yang pernah dibacakan Abu Hurairah di hadapan orang ramai, "(Tetapi) ada juga di antara manusia yang mengorbankan dirinya untuk mencari keridoan Allah..." (Qs. 2:207). Dengan demikian, menurut Ibn Nuhas, aksi bunuh diri istimata atau istisyhad adalah sah.Pendapat Ibn Nuhas inilah yang dijadikan referensi bagi Imam Samudra bahwa bom bunuh diri dalam konteks penyelamatan diri dari musuh adalah sangat dianjurkan. Muhammad Haniff Hassan, Pray to Kill (Jakarta: Grafindo, 2006), 28; Yoyo Hambali, "Hukum Bom Bunuh Diri Menurut Islam Radikal dan Islam Moderat”, Maslahah, Vol.1, No. 1, Juli $2010,52$.

${ }^{10}$ Hwang, Why Terrorists Quit, 2. 
umum), taklim (wacana agama bagi pengikut dengan jumlah kecil), tamrin (sesi pembelajaran agama tertutup), tamhish (tingkat tinggi)."

Islam sangat menentang tindakan terorisme karena mencelakakan diri sendiri dan bunuh diri. Dalam al-Qur'an dijelaskan Dan janganlah kamu menjatuhkan dirimu sendiri ke dalam kebinasaan (Qs. alBaqarah/2: 195); Dan janganlah kamu membunuh dirimu (Qs. an-Nisa>'/4: 29). Demikian juga hadis Nabi Muhammad Saw Tidak boleh ada bahaya dan tidak boleh membahayakan orang lain (HR. Ibnu Ma>jah); Barangsiapa yang membunuh dirinya dengan sesuatu, ia akan di azab dengan itu di hari kiamat" (HR. Bukhari dan Muslim). ${ }^{12}$

Secara psikologis, sebagaimana dijelaskan Rex A. Hudson dalam teori psikologi teroris(the psychology of the terrorist), seorang teroris melakukan aksinya karena termotivasi dan tekanan dari kelompoknya, rasionalisasi pembenaran aksi kekerasan, dan dorongan fanatisme untuk mati sahid. ${ }^{13}$ Jika aksi terorisme ditayangkan melalui media, para teroris merasa senang karena aksinya dianggap sebagai "pejuang kebebasan" (freedom fighters). ${ }^{14}$ Sebaliknya, para korban aksi teorisme cenderung memiliki sikap "bias optimis" (optimistic bias), yaitu suatu perasaan yang rentan terhadap resiko, ${ }^{15}$ rakyat dan keluarga korban mengalami tekanan dan ketakutan.

Tulisan ini menjelaskan tentang apa itu terorisme, strategi perekrutan terorisme melalui media sosial, dan langkah-langkah pencegahan aksi terorisme di Indonesia.

\section{Literature Review}

Penelitian yang menjelaskan relevansi terorisme dan media sosial yang mempengaruhi psikologi calon teroris telah dilakukan oleh beberapa peneliti sebelumnya.

Pertama, Nilay Saiya dalam The Roots of Religious Terrorism yang menjelaskan penyebab beberapa negara melakukan aksi terorisme. Nilay Saiya menyimpulkan bahwa terorisme yang dilakukan atas nama agama bukanlah disebabkan oleh kemiskinan, gangguan psikologis atau pendudukan asing, tetapi lebih disebabkan oleh negara-negara yang menindas hak-hak agama dan politik kelompok-kelompok dan individu-individu umat agama. Dengan adanya bentuk penindasan seperti ini, terorisme agama melawan rezim yang menolak kebebasan beragama bagi penganutnya.Pendekatan yang dilakukan Nilay Saiya adalah menggunakan suatu analisis statistik dari gerakan-gerakan terorisme agama di beberapa kasus berbagai negara. ${ }^{16}$

Kedua, penelitian yang dilakukan Eran Shor dalam Terrorism and Counterterrorism: A Comparative Cross-National Analysis. Penelitian ini secara sistematis menganalisa hubungan antara terorisme oposisi dan kebijakan-kebijakan negara, dengan menggunakan analisis regresi cross-sectional time seriesdanthe logic of socio-institutional and cultural theoretical approaches dari database lintas negara berskala besar (kumpulan beberapa studi terorisme). Penelitian ini menguji dampak gerakan terorisme dan faktor-faktor lainnya terhadap perbedaan kebijakan pemerintah dan kebijakan terorisme.Pertama, melalui pendekatan rational-action logic disimpulkan bahwa beberapa negara gagal mengikuti atau mematuhi instrumen logis

${ }^{11}$ Nasir Abas, Membongkar Jamaah Islamiyah: Pengakuan Mantan Anggota JI (Jakarta: Grafindo Khazanah Ilmu, 2005), 99-100; Miichi Ken, "Looking at Links and Nodes: How Jihadists in Indonesia Survived", Southeast Asian Studies, Vol. 5, No. 1 (April 2016): 139.

${ }^{12}$ Muhammad Haniff Hassan, Civil Disobedience in Islam: A Contemporary Debate (Singapore: Palgrave Macmillan, 2017), 95.

${ }^{13}$ Rex A. Hudson, Who Becomes a Terrorist and Why?The Sociology and Psychology of Terrorism(New York: Skyhorse Publishing, 2018)

${ }^{14}$ Michael B. Kraft, "Evolution of U.S. Counterterrorism Laws, Policies, and Programs", in Evolution of U.S.Counterterrorism Policy, Yonah Alexander and Michael B. Kraft (London: Praeger Security International, 2008$), 8$.

${ }^{15}$ Aaron M. Hoffman and William Shelby, "When the "Laws of Fear" Do Not Apply: Effective Counterterrorism and the Sense of Security from Terrorism", Political Research Quarterly, Vol. 70, 3, (2017): 623 (618-631).

${ }^{16}$ Nilay Saiya, The Roots of Religious Terrorism, Dissertation, Graduate Program in Political Science Notre Dame, Indiana, 2013. 
rasional-tindakan yang dirumuskan oleh para peneliti terorisme, di mana kebijakan-kebijakan kontraterorisme - dengan instrumen logis rasional-tindakan - secara langsung merespon tindakan terorisme secara internal. Kedua, melalui pendekatan the logic of socio-institutional and cultural theoretical approaches, yang diyakini bisa menjadi analisis yang paling tepat untuk melakukan kebijakankebijakan kontra terorisme. Namun pendekatan ini pun belum menyelesaikan masalah karena kebijakan terhadap kontraterorisme masih ada celah (terhadap kebijakan kontraterorisme di beberpa negara), perbedaan tradisi budaya (terutama budaya demokratis), dan berbagai ancaman domestik. Eran Shor dalam penelitian Terrorism and Counterterrorism: A Comparative Cross-National Analysis (2010) ini menyimpulkan bahwa kebijakan-kebijakan kontrateroris secara umum tidak efektif dalam mengurangi kegiatan terorisme di masa mendatang. Melalui analisa seperti ini, Eran mengharapkan dilakukannya langkah penting yang lebih baik bagi pemerintah di berbagai negara, seperti format kebijakan pemerintah dalam melakukan kontraterorisme. ${ }^{17}$

Ketiga, penelitian Rose Bellandi dalam Terrorist Ideology and Behavior: An Examination of the Behavior of Known and Unknown Perpetrators ${ }^{18}$ yang membahas tentang target dan sasaran ideologi terorisme. Aspek-aspek yang diteliti adalah: tujuan rekrutmen kelompok jangka panjang, tujuan rekrutmen jangka pendek, tujuan serangan, masyarakat, simpatisan teroris, musuh-musuh teroris, dan pesan-pesan. Menurut Rose, terorisme adalah suatu taktik peperangan asimetris dan bentuk kejahatan yang unik. Aksi terorisme dan pelakunya dilakukan dalam berbagai bentuk, yang menghadirkan berbagai ancaman kekerasan yang berbeda, dan terjadi dalam serangkaian keadaan yang sulit diketahui. Dengan menggunakan data-data ideologi kelompok teroris di data pribadinya, the Global Terrorism Database, Polity IV, the Political Instability Taskforce, dan Major Episodes of Political Violence, Rose meneliti hubungan antara ideologi teroris dan perilaku teroris. Pertama, dia menghubungkan sejumlah pelaku teroris dari masing-masing jenis ideologi dan mengevaluasi serangan-serangan pembunuhan, serangan bersenjata yang mereka lakukan dalam menentang bisnis, pemerintah, polisi, militer, dan target-target sipil. Kedua, dia mengevaluasi dampak ideologi terhadap pengendalian perilaku teroris yang telah menyebabkan kekerasan politis dan ketidakstabilan, geografis, waktu, dan variabel-variabel negara dan kelompok teroris.Ketiga, dia mengevaluasi perilaku teroris yang tidak diketahui secara keseluruhan dan antara 1998 hingga 2013.

Rose menyimpulkan: Pertama, ada hubungan antara ideologi teroris dan perilaku teroris. Kedua, beberapa perilaku teroris sesuai dengan seluruh ideologi dan perjalanan waktu. Akhirnya aksi-aksi terorisme yang dilakukan oleh para pelaku tidak diketahui karena secara geografis tersentralisir dan pola perilaku mereka sama dengan perilaku pelaku umumnya.

Keempat, penelitian yang dilakukan Rafael Edmundo Linera Rivera, "Social Representations of Threat in Extended Media Ecology: Sochi 2014 Olympics, Jihadist Deeds, and Online Propaganda”. Pendekatan yang dilakukan dalam penelitian ini menggunakan teori semiotik, repesentasi sosial, dan pengaruh minoritas dalam mengeksplorasikan bagaimana konten imej (image) dan bahasa (language) dari serangan-serangan teroris (29 - 30 Desember 2013) dan vidio propaganda online serangan mereka (18 Januari 2014) dalam menentang The Sochi 2014 Winter Olympics yang diterjemahkan kepada platform media mainstream dan Twitter. Konten vidio ini adalah tentang tema-tema kesahidan, patriotisme, dan seruan jihad.Konten ini juga diterjemahkan ke berbagai bahasa di berbagai media.Dari penelitian ini dijelaskan Rafael Edmundo Linera Rivera bahwa secara psikologis masyarakat merasa terancam, tertekan, dan takut oleh media sosial yang disebarkan oleh teroris.Penelitian ini juga sejalan dengan studi Cantril (tentang ketakutan dan

\footnotetext{
${ }^{17}$ Eran Shor, "Terrorism and Counterterrorism: A Comparative Cross-National Analysis", Dissertation, Sociology Stony Brook University, 2010.

${ }^{18}$ Rose Bellandi, "Terrorist Ideology and Behavior: An Examination of the Behavior of Known and Unknown Perpetrators", Dissertation, School of Criminal Justice, The University at Albany, State University of New York, 2016.
} 
Sustainable, Vol. 3 No. 1, 2020, $35-52$.

skeptisisme yang disebarkanluaskan kepada publik) dan studi Barlett (tentang metodologi konvensionalisasi dan reproduksi serial). ${ }^{19}$

Kelima, penelitian yang dilakukan Mirra Noor Milla Dinamika Psikologis Perilaku Terorisme: Identitas dan Pengambilan Keputusan Jihad di Luar Wilayah Konflik pada Terpidana Kasus Bom Bali Di Indonesia. ${ }^{20}$ Penelitian ini menjelaskan dinamika psikologis perilaku terorisme yang meliputi pembentukan identitas dan pengambilan keputusan jihad di luar wilayah konflik pada terpidana kasus Bom Bali di Indonesia. Pendekatan yang dilakukan dalam penelitian ini adalah naratif fenomenologis, yaitu analisis yang dilakukan berdasarkan data hasil wawancara, dokumentasi (manuskrip, surat pribadi, rekaman audio, rekaman audiovisual dan autobiografi yang dipublikasikan), dan observasi. Penelitian ini menyimpulkan bahwa: Pertama, pelaku teror tidak selalu memiliki predisposisi psikologis yang mengarah kepada perilaku terorisme, seperti frustasi dan traumatis. Kedua, para teroris Bom Bali ini adalah individu yang melakukan sub-ordinasi identitas personal ke dalam identitas kelompok berdasarkan kelompok keagamaan.Dengan demikian, ketika ancaman ditujukan kepada kelompok mereka, identitas mereka masih kuat. Ketiga, keputusan jihad di luar wilayah konflik masih bias karena kepercayaan diri mereka sangat berlebihan (faith-side bias), tekanan konformitas (hanya satu solusi terbaik segera diputuskan (decisiveness), dan adanya stereotype bahwa di luar kelompok (outgroup) adalah kompetitor dan musuh.

Keenam, penelitian yang dilakukan oleh Brenna Durr dalam ISIS: The Use of Social Media. ${ }^{21}$ Penelitian Brenna ini menguji penggunaan media sosial yang dilakukan ISIS melalui penyebaran proganda.Brenna menyimpulkan bahwa ISIS telah mengembangkan divisi kampanye propaganda dengan teknologi canggih yang disebut the Al-Hayat Media Center.Al-Hayat adalah suatu cabang media ISIS yang targetnya adalah masyarakat Barat dan negara yang tidak berbahasa Arab.ISIS juga mengembangkan propaganda dengan menggunakan media sosial seperti Facebook, Twitter, and Youtube.ISIS akan terus tumbuh dengan media sosial dan internet. Menurut Brenna, penanggulangan perlu dilaksanakan oleh pemerintah di tingkat lokal dan federal, tetapicara seperti ini menjadi perdebatan karena menghalangi kebebasan berbicara dan pelanggaran privasi di berbagai negara.Namun, plaform media sosial saat ini mampu memberikan pencegahan terhadap propaganda, perekrutan, dan metode pendanaan melalui media sosial yang dilakukan ISIS. Brenna memberikan solusi perlunya penanggulangan dan pemantauan ISIS oleh pemerintah di setiap negara.Sedangkan pendekatan penelitian Brenna ini adalah comparative approach dan historis.

Tulisan ini memiliki persamaan dengan penelitian-penelitian sebelumnya, yaitu tentang gerakan terorisme. Adapun perbedaan tulisan ini dengan lainnya bahwa tulisanini menggunakan pendekatan psikologis dalam menganalisis aksi terorisme dalam level mikro (individu dan kelompok). Pendekatan psikologis ini mengaplikasikan teori, proses rekrutmen, dan induksi ke dalam kelompok, kepribadian, kepercayaan, sikap, motivasi, dan karir sebagai teroris.

\section{Metode}

Tulisan ini merupakan riset lapangan (field research) dengan mengkaji data-data tentang gerakan terorisme baik perekrutan calon teroris melalui media sosial maupun pencegahannya di Indonesia.Sedangkan metode yang digunakan adalah analisiskualitatif.Data-data yang telah dihimpun,

${ }^{19}$ Rafael Edmundo Linera Rivera, "Social Representations of Threat in Extended Media Ecology: Sochi 2014 Olympics, Jihadist Deeds, and Online Propaganda”, Dissertation, Fielding Graduate University, Santa Barbara, California, 2016.

${ }^{20}$ Mirra Noor Milla, "Dinamika Psikologis Perilaku Terorisme: Identitas dan Pengambilan Keputusan Jihad di Luar Wilayah Konflik pada Terpidana Kasus Bom Bali Di Indonesia”, Disertasi, Universitas Gajah Mada, 2009.

${ }^{21}$ Brenna Durr, "ISIS: The Use of Social Media". Thesis, The Faculty of Utica College, 2016. 
selanjutnya disusun secara sistematis dan periodik, dibandingkan, dan dianalisa. Langkah-langkah yang dilakukan adalah menjelaskan: siapa teroris, penggunaan media sosial dalam propaganda dan rekrutmen calon teroris di Indonesia, pengaruh media sosial secara psikologis bagi calon teroris, dan langkah-langkah strategis untuk menghindari atau mengurangi gerakan terorisme bagi calon teroris di Indonesia.

Adapun pendekatan yang digunakan adalah pendekatan Psikologi Teroris(The Psychology of the Terrorist)Rex Hudson. Teori psikologi teroris Hudson ini meliputi: a. motivasi teroris (terrorist motivation) b. proses bergabungnya sekelompok teroris (the process of joining a terrorist group) c. teroris sebagai orang yang sakit mental (the terrorist as mentally ill) d. teroris sebagai orang fanatik yang bunuh diri (the terrorist as suicidal fanatic) e. dinamika kelompok teroris: pressures to conform, pressures to commit acts of violence, terrorist rationalization of violence $\mathrm{f}$. ideologi teroris atau persepsi agama. ${ }^{22}$ Beberapa jenis teori Hudson ini akan dijadikan acuan pembahasan penelitian.

\section{Apa itu Terorisme?}

Gerakan terorisme di suatu negara harus dibasmi dan dilarang agar stabilitas nasional negara terpelihara dengan baik. Namun, pelarangan dan pemberantasan terorisme negara (state terrorism) oleh pemerintah kadangkala dipahami oleh sebagian masyarakat sebagai pelanggaran tindakan kekerasan, pelanggaran Hak Asasi manusia, dan anti agama (Islam). Dalam analisa Blakeley, setidaknya terdapat empat elemen bahwa tindakan kekerasan itu disebut sebagai terorisme negara (state terrorism), yaitu: 1. Melakukan tindakan kekerasan dan ancaman kepada seseorang; 2. Mengancam para pembela negara, termasuk militer dan agen keamanan non-pemerintah; dan 4. memaksa masyarakat agar merubah perilaku mereka dengan berbagai cara. ${ }^{23}$

Kata teroris diambil dari akar kata terror (Inggris) dan terrere (Latin) yang berarti menakuti.Sedangkan kata terorisme berarti memaksa dengan disertai dengan ancaman kekerasan. ${ }^{24}$ Dalam bahasa Arab, Ezeldin (1987) menegaskan bahwa dalam bahasa Arab modern, kata teror berasal dari kata Irhab yang diambil dari akar kata rahbah, yang berarti takut atau horror. Irhab atau terorisme berasal dari kata kerja (fíil)arhaba, yang berarti diteror. ${ }^{25}$

Kata terorisme yang bermakna menakutkan ini, menurut Lil-Malayin (2007),disebabkan oleh tindakan kekerasan yang dilakukan oleh pelaku teroris, seperti pembunuhan, melempar geranat, dan sabotase. Sedangkan seorang teroris (Al-Irha>bi>)adalah orang yang beralih ke terorisme dengan cara membunuh atau memasang alat peledak untuk menegakkan rezim politiknya atau menggulingkan orang lain. ${ }^{26} \mathrm{~J}$. Nassar berpendapat bahwa teroris merupakan label politik yang diberikan kepada orang-orang yang berencana atau melakukan tindakan kekerasan untuk kepentingan politik. Definisi seperti ini menunjukkan bahwa terorisme biasanya bermuatan politis, mengandalkana kekerasan, dan melibatkan organisasi dan bukan individual. ${ }^{27}$

Joseph K. Young dalam sebuah artikelnya What is terrorism? menjelaskan bahwa kata terorisme dapat didefinisikan berdasarkan bagaimana gerakan terorisme itu diorganisir dan dilakukan. ${ }^{28}$ Menurut

${ }^{22}$ Hudson, Who Becomes a Terrorist and Why?

${ }^{23}$ Andrew Silke, State Terrorism in Andrew Silke (ed.), Rourledge Handbook of Terrorism and Counterrorism (New York: Routledge, 2019); R. Blakeley, State Terrorism in the Social Sciences: Theories, Methods, and Concept in R. Jackson, E Mutphy and S. Poynting (eds.), Contemporary State Terrorism: Theory and Practice (London: Routledge, 2009), 5.

${ }^{24}$ Michael Chimaobi Ochu and Thapelo J. Otlogetswe, "The Study of Terror, Terrorise, Terrorism, Terrorist in Two Nigerian Newspapers", Marang: Journal of Language and Literature 30 (2018).

${ }^{25}$ A. Ezeldin, Terrorism and political violence: An Egyptian Perspective (Chicago: Office of International Criminal Justice, University of Illinois 1987).

${ }^{26} \mathrm{~J}$. Lil-Malayin, A New Collocation Extraction Method: Combining Multiple Association Measures. Proceedings of the Seventh International Conference on Machine Learning and Cybermetrics, Kumming (2007): 12-15.

${ }^{27} \mathrm{~J}$. Nassar, Globalization and Terrorism: The Migration of Dreams and Nightmares (Lanham: Rowman \& Littlefield, 2005), 17.

${ }^{28}$ Joseph K. Young, "Measuring Terrorism," Terrorism and Political Violence, 31.2 (2019): 323-345. 
Andrew Silke, kata terorisme secara mendasar diartikan sebagai suatu istilah perojatif yang bermakna negatif. Dalam hal politik, pejuang kemerdekaan bagi rakyat yang tertindas bisa dimaknai sebagai teroris bagai rival politisi lainnya. Misalnya Nelson Mandela yang membela kemerdekaan rakyat disebut sebagai teroris. ${ }^{29}$ Leonard Weinberg and William L. Eubank menambahkan bahwa terorisme adalah suatu taktik, bukan suatu ideologi yang digunakan oleh beberapa kelompok dengan tujuan menghalangi perubahan sosial dan lawan politik. ${ }^{30}$

Dalam analisa Graeme Newman dan Ronald V. Clarke, terorisme adalah pemanfaatan kekuatan atau kekerasan untuk menindas atau merampas kekayaan dengan cara mengintimidasi atau memaksa pemerintah, masyarakat sipil atau berbagai wilayah dengan tujuan politik atau sosial. ${ }^{11}$ Wilkinson mendefinisikan terorisme sebagai suatu tindakan yang direncanakan atau diciptakan untuk memberikan rasa takut atau teror kepada masyarakat sehingga para korban terorisme menderita baik secara fisik maupun psikis. ${ }^{32}$

Terorisme didefinisikan sebagai manifestasi strategis dalam suatu agenda politik yang dilakukan oleh keompok-kelompok teroris.33Berbeda lagi dengan D. Lewis yang mendifnisikan terorisme dengan istilah narco-terrorism. Istilah narco-terrorism ini dikaitkan dengan peredaran narkoba di Asia Tengah di mana hasil perdagangan narkoba digunakan untuk mendanai aktivitas teroris melalui perdagangan narkoba (drug trafficking) dan cara seperti ini merupakan bagian terpenting dalam wacana jaringan kejahatan teror (crime-terror nexus discourse). ${ }^{34}$

Terorisme juga diartikan sebagai bentuk distingsi agen politik modern yang bertujuan untuk mengancam keamanan negara. Definisi seperti ini, menurut Sunil Khilnani, lebih identik dengan istilah teror, yaitu suatu cara melakukan kekerasan secara acak (random). 35

Beberapa negara sepakat bahwa terorisme adalah masalah global yang tidak bisa diselesaikan oleh satu negara, tetapi perlu upaya bersama-sama untuk menyelesaikannya. Terorisme juga tidak hanya terjadi pada era modern, tetapi telah terjadi sepanjang masa dengan berbagai bentuk.Gerakan terorisme di era modern dilakukan dengan membunuh para korban dan sangat sulit untuk diatasi. ${ }^{36}$

Lalu, apa yang dimaksud dengan terorisme agama (religious terrorism)? Terrorisme agama dicirikan oleh ketaatan seseorang pada keyakinan, ${ }^{37}$ untuk memajukan dan mempertahankan agama, ${ }^{38}$ dan bahkan untuk tujuan politik tertentu. ${ }^{39}$ Terorisme agama juga diasosiasikan kepada kelompok-kelompok Islam fundamentalisme yang melakukan serangan-serangan, terutama peristiwa pada 11 September 2001. ${ }^{40}$ Lorne L. Dawson, dalam penelitiannya melalui wawancara kepada pejuang Barat di Siria dan Iraq,

\footnotetext{
${ }^{29}$ Andrew Silke, The Study of Terrorism and Counterterrorism (London/New York: Routledge, 2019).

${ }^{30}$ Leonard Weinberg and William L. Eubank, What Is Terrorism?(New York: Chelsea Publishing, 2006), 46.

${ }^{31}$ Graeme Newman and Ronald V. Clarke, Terrorism in Mangai Natarajan, ed.,International and Transnational Crime and Justice (New York: Cambridge University Press 2019), 148.

${ }^{32} \mathrm{P}$. Wilkinson, International Terrorism New Risks to World Order in J. Balylis and N. Rengger (eds.), Dilemmas of World Politics International Issues in a Changing World (London: Clarenden Press, 1992), 228; Dag Arne Christensen and Jacob Aars, "Does Democracy Decrease Fear of Terrorism?" Terrorism and Political Violence 31.3 (2019): 615-631.

${ }^{33}$ Emma Wilson, "Combatting Organised Crime and Terrorism in Central Asia," (2018).

${ }^{34}$ Lewis, D, "Crime, terror and the state in Central Asia", Global Crime, 15 (2014): 337

${ }^{35}$ Charles Townshend, Terrorism: A Very Short Introduction (Oxford and New York: Oxford University Press, 2018),

5.

${ }^{36} \mathrm{Comb}$ and Slann, Encyclopedia of Terrorism, xi.

${ }^{37}$ Sebagai contoh Boko Haram di Nigeria. Lihat E. U. Ejeh, A. I. Bappah, and Yusuf Dankofa, "Nature of Terrorism and Anti-Terrorism Laws in Nigeria," Nnamdi Azikiwe University Journal of International Law and Jurisprudence, 10.2 (2019): 186-192.

${ }^{38}$ Ofir Falk, "Terrorism: Agreeing on the Basics", American Diplomacy (2019): 1-7.

${ }^{39}$ Lorne L. Dawson, "Challenging the Curious Erasure of Religion from the Study of Religious Terrorism", Numen, 65.2-3 (2018): 141-164.

${ }^{40}$ Werner Bohleber, "Collective Phantasms, Destructiveness, and Terrorism," in Svere Varvin and Vamik D. Volkan (Eds.), Violence or Dialogue? Psychoanalytic Insight on Terror and Terrorism (London: Routledge, 2018. $111-130$.
} 
menyimpulkan bahwa motif dilakukannya terorisme agama adalah berjihad (jihadist). ${ }^{41}$ Aksi terorisme agama ini lebih mematikan daripada aksi teroris umumnya.

Mohamed Bin Ali mengamati bahwa terorisme agama ada relevansinya dengan konsep Islam Salafi al-wala' wa al-bara' (loyalitas dan pengingkaran). Bagi Salafisme modern, konsep al-wala' wal bara' menjadi bagian yang tidak terpisahkan dalam diri setiap Muslim. Istilah wala' merujuk kepada penyembahan diri Muslim kepada Tuhan (Tawh\}i>d), sedangkan bara' merujuk kepada pengingkaran kepada selain Tuhan. Sayangnya, konsep wala'wal bara' ini telah dimasukkan ke dalam kurikulum sekolah di Saudi. Mantan Menteri Pendidikan Saudi, Abdullah Al-Ubayd, telah menyampaikan bahwa kurikulum ini tidak cocok dengan ajaran Islam yang rahlmatan li al-'a>lami>n dan menjadi instrumen berkembangnya ideologi jihadi dan berkontribusi kepada terorisme. ${ }^{42}$

Dawn Perimutter berpendapat bahwa definisi terorisme agama sangat problematis karena konsep terorisme agama secara relatif ditentukan oleh perspektif teologis, moral, politik, sosiologis, dan hukum masing-masing kelompok. Di sini, terorisme agama sering dihubungkan dengan kelompok yang "mengkultuskan diri", yaitu "satu orang mengaku Dewa dan yang lainnya setan" dan "satu orang mengaku teroris dan yang lainnya pejuang kebebasan (muja>hid)". 43

Dari berbagai definisi di atas, penulis tidak sependapat apabila gerakan terorisme dilakukan dengan alasan apapun, apakah alasan agama, politik, ekonomi, dan sebagainya. Aksi terorisme sangat bertentangan dengan rah\}matan li al-'a>lami>n, Pancasila, UUD 1945, Negara Kesatuan Republik Indonesia, dan Bhinneka Tunggal Ika.

\section{Media Sosial sebagai Alat Propaganda Rekrutmen Calon Teroris di Indonesia}

Dalam konteks terorisme dan radikalisme, media mengkonstruksi realita yang berbeda dengan realitas sosial kehidupan sehari-hari. Tujuan propaganda terorisme yang tersebar di media sosial, sebagaimana dijelaskan oleh United Nations Office on Drug and Crime (UNODC) meliputi: a. mempromosikan tindakan kekerasan b. mempromosikan retorika para ekstrimis yang memberikan dukungan kepada aksi kekerasan c. perekrutan d. penghasutan, dan e. radikalisasi. ${ }^{44}$ Kegiatan teroris di dunia siber pada umumnya meliputi 9 P, yaitu: Propaganda, Perekrutan, Pelatihan, Penyediaan logistik, Pembentukan paramiliter secara melawan hukum, Perencanaan, Pelaksanaan serangan teroris, Persembunyian, dan Pendanaan. ${ }^{45}$

Rekrutmen calon teroris melalui media sosial memang menjadi sarana yang efektif bagi kelompok teroris. Sebagai contoh, propaganda yang dilakukan oleh ISIS yang mengandalkan bukan hanya kelompokkelompok radikal tetapi juga media sosial (social media), seperti websites, Facebook danTwitters. ${ }^{46}$ Berdasarkan penelitian internal BNPT, lading utama kelompok ISIS adalah dunia maya. Bahkan ISIS mengalokasikan keuangannya hampir $50 \%$ untuk kepentingan media. ${ }^{4}$ ISIS cukup mahir dalam

\footnotetext{
${ }^{41}$ Lorne L. Dawson, "Debating the Role of Religion in the Motivation of Religious Terrorism," Nordic Journal of Religion and Society, 31.02 (2018): 98-117.

${ }^{42}$ Mohamed Bin Ali, The Roots of Religious Extremism: Understanding the Salafi Doctrine of Al-Wala' Wal Bara' (London: Imperial College Press, 2016), 1-3 dan 171.

${ }^{43}$ Dawn Perimutter, Investigating Religious Terrorism and Ritual Crimes (Boca Raton, London, New York, and Washington, D.C.: CRC Press, 2004), 1.

${ }^{44}$ United Nations Office on Drug and Crime, 2012, 3. 2015), 31 .

${ }^{45}$ Petrus Reinhard Golose, Invasi Terorisme ke Cyberspace (Jakarta: Yayasan Pengembangan Kajian Ilmu Kepolisian,

${ }^{46}$ Francisco Galamas, "Terrorism in Indonesia: An Overview", Research Papers 4 (2015): 10.

${ }^{47}$ Benedicta Dian Ariska Candra Sari, "Media Literasi dalam Kontra Propaganda Radikalisme dan Terorisme melalui Media Internet", Peperangan Asimetrik 3.1 (2017).
} 
memanfaatkan media sosial secara efektif sehingga memberi ruang bagi kelompok ini untuk menyebarkan dan merekrut anggota baru dari seluruh dunia, termasuk Indonesia. ${ }^{48}$

Untuk melancarkan aksinya, teroris melakukan propaganda dengan tujuan mempromosikan retorika para ekstremis yang memberikan dukungan kepada aksi kekerasan, perekrutan, penghasutan, dan radikalisasi. ${ }^{49}$

Radikalisasi, menurut Muhammad Tito Karnavian sebagaimana ditulis di disertasinya pada tahun 2013, pada dasarnya adalah mengenai pengiriman pesan dari seorang pengirim (sumber) kepada seorang penerima (sasaran). Definisi yang dijelaskan Karnavian merupakan kombinasi teori penyebab teroris Louis Richardson dan teori komunikasi Seboek. Penggabungan kedua teori ini menurut Karnavian merupakan model deradikalisasi dan kontra-radikalisasi. Kesimpulan deradikalisasi ini dilakukan Karnavian setelah setelah mengamati Berita Acara Pemeriksaan (BAP) terpidana teroris dan wawancara secara intensif dengan 62 orang pelaku dan mantan pelaku tindak pidana terorisme. ${ }^{50}$

Untuk menyimpulkan apakah seseorang tergolong deradikalisasi atau bukan, menurut Karnavian harus berangkat dari lima unsur deradikalisasi, antara lain: 1. pengirim (recruiter) 2. penerima (recruits) 3. pesan dalam bentuk ideologi pembenar (legitimising ideology) 4. saluran(method of radicalisastion), yang dilakukan baik dengan tatap muka maupun media sosial, dan 5 . konteks(context), baik konteks politik, sosial-ekonomi maupun budaya tempat di mana penerima pesan (receiver) hidup, termasuk konteks internal atau psikologisnya, dan sebagainya. Menurut Karnavian, proses radikalisasi akan berjalan dengan baik jika kelima unsur di atas mendukung radikalisasi. Sebaliknya, jika salah satu unsur itu tidak terpenuhi maka proses radikalisasi tidak berjalan dengan sukses. Oleh karena itu, menurut Karnavian, untuk menetralisasi kelima unsur tersebut perlu adanya model deradikalisasi dan kontra-radikalisasi, yaitu: 1. melemahkan narasi dari ideologi kekerasan 2. melemahkan para perekrut 3. menetralissasi orang-orang yang potensial direkrut 4. melemahkan metode radikalisasi, dan 5. memperbaiki konteks, terutama konteks eksternal yang bisa memfasilitasi proses radikalisasi. ${ }^{51}$

Demikian juga kelompok ISIS, dalam hal produksi dan penyebaran propaganda, menggunakan official propaganda dan unofficial propaganda. Pertama, official propaganda maksudnya adalah ISIS memproduksi materi-materi propaganda berupa video, foto, dan tulisan-tulisan yang diterbitkan secara profesional memlalui media resmi milik ISIS, di antaranya Al-Hayat Media Center (didirikan pada pertengahan 2014) yang disiarkan dalam bahasa Jerman, Inggris, Perancis, dan Rusia. ${ }^{22}$

Propaganda yang dilakukan oleh teroris, menurut Petrus Renhard Golose, melalui tiga tahapan:

1. Propaganda by deed yang dilakukan sebelum serangan teror.

Sebagai contoh jenis propaganda ini adaah bom JW Marriot tahun 2009 yang dilakukan oleh Dani Dwi Permana. Sebelum melakukan aksinya, Dani menerima pesan seperti: alasan melakukan aksi bom bunuh diri, wasiat untuk minta maaf kepada keluarga dan orang-orang terdekat,dan pesan kepada kelompok tertentu untuk mengikuti jejak mereka. Pesan sebelum melakukan aksi bom bunuh diri diharapkan agar pelakunya mendapat pembenaran dan pengikutnya bisa meniru. Padahal tindakn bunuh diri dan membunuh orang lain dilarang oleh agama.

\footnotetext{
${ }^{48}$ Santi Dwi Putri dan Fendy Eko Wahyudi, "Cyber Terrorism: Strategi Propaganda dan Rekrutmen ISIS di Internet dan Dampaknya bagi Indonesia Tahun 2014-2019", Journal of International Relations 5.4 (2019): 827-833.

${ }^{49}$ Andi Widiatno, "Tinjauan Yuridis Penanggulangan Tindak Pidana Terorisme dalam Menyebarkan Propaganda Melalui Media Sosial", Hukum Pidana dan Pembangunan Hukum 1.1 (2018).

${ }^{50}$ Untuk lebih jelasnya bisa dibaca pada buku Muhammad Tito Karnavian, Explaining Islamist Insurgencies: the Case of al-Jamaah al-Islamiyyah and the Radicalisation of the Poso Conflict, 2000-2007 (London: Imperial College Press, 2015); Ihsan Ali-Fauzi dan Solahudin, Deradikalisasi di Indonesia dalam Ihsan Ali-Fauzi, dkk (Editor),Kebebasan, Toleransi dan Terorisme: Riset dan Kebijakan Agama (Jakarta: Pusat Studi Agama dan Demokrasi, 2017), 256.

${ }^{51}$ Karnavian, Explaining Islamist Insurgencies, 235-237; Ali-Fauzi dan Solahudin, Deradikalisasi di Indonesia, 256.

${ }^{52}$ Bill Gertz, "New Al Qaeda Group Produces Recruitment Material for Americans, Westerners", The Washington Free Beacon, 2014.
} 
2. Propaganda by deed yang propaganda yang dilakukan setelah aksi.

Jenis propaganda ini disampaikan setelah selesai melakukan serangan. Propaganda ini bertujuan untuk menggalang kekuatan organisasi dan mencari dukungan dari kelompok tertentu. Bagi teroris, serangan yang dilakukan merupakan kewajiban untuk membasmi thaghut dengan harapan agar orang-orang yang melakukan aksinya menyalahkan pemerintah. Ciri khas propaganda jenis ini menggunakan name calling (mengajak dengan kata-kata provokatif yang berupaya merendahkan pemerintah).

3. Propaganda by deed yang dilakukan selama aksi

Propaganda jenis ini dilakukan pada saat aksi troris sedang berlangsung baik yang dilakukan sendiri maupun melalui media massa. Contonya, serangan teroris di menara kembar WTC di Amerika Serikat pada 11 September 2001 yang menyebabkan 2.00o orang meninggal dunia. Berita aksi teroris ini disiarkan melalui media massa terutama televisi. Penyiaran serangan teror ini menimbulkan ketakutan bagi masyarakat Amerika Serikat dan seluruh dunia. ${ }^{53}$

Namun, sejak Juli 2014 Al-Hayat beralih ke majalah digital bernama Dabiq yang terbit dengan edisi 115 yang ditulis dalam bentuk artikel dengan format yang lebih panjang dengan perubahan gaya bahasa yang lebih berwibawa dan formal. Selanjutnya majalah digital Dabiq berganti nama majalah digital Rumiyah yang lebih berpengaruh dalam aksi propaganda ISIS dengan jangkauan yang lebih luas, meskipun sederhana. ${ }^{54}$ Majalah digital Rumiyah ini diterjemahkan ke dalam 10 bahasa, yaitu Inggris, Bahasa, Bosnia, Perancis, Jerman, Kurdi, Pashto, Rusia, Turki, dan Uyghur. ${ }^{55}$

Kedua, unofficial propaganda yaitu propaganda yang tidak dibuat dan disebarkan oleh ISIS, tetapi propaganda dilakukan oleh para pendukung mereka dari seluruh dunia dan tersebar di berbagai platform media sosial. ISIS menyadari bahwa akun resmi mereka pada platform seperti You Tube , Facebook dan aplikasi yang mereka buat pada sistem android tidak akan berlangsung lama dikarenakan diawasi secara ketat dan dikukuhkan oleh pihak pemerintah yang berwenang. Semua pesan yang dipublikasikan oleh para pendukung ISIS secara online ini dikemas dan dikembangkan secara profesional dan emosional yang dapat menyentuh semua orang. ${ }^{6}$

Bagaimana dengan perekrutan calon teroris melalui media sosial di Indonesia?Internet adalah senjata ampuh untuk menyebarkan ideologi bagi kelompok teroris.Hingga tahun 2015, telah ada lebih dari 9000 website yang dianggap mengandung unsur radikal. ${ }^{57}$ Jika melihat fakta ini, tidak mengherankan jika teroris memanfaat internet untuk mempropaganda anak muda dikarenakan sebagian besar pengguna internet adalah anak muda yang berusia rata-rata $17-25$ tahun. ${ }^{5}$ Propaganda ini mampu merubah fisik, psikologis, dan mindset anak muda.

Kaum perempuan, yang secara sosiologis adalah kelompok rentan (the vulnerable groups) yang mudah mengakses media sosial.

Tidak hanya kaum lelaki, kaum perempuan pun yang memiliki keterbatasan literasi dan daya kritis lebih mudah menerima informasi dan pelajaran keagamaan dari media sehingga mereka mudah

\footnotetext{
${ }^{53}$ Golose, Invasi Terorisme ke Cyberspace; Widiatno, "Tinjauan Yuridis Penanggulangan Tindak Pidana Terorisme.

${ }^{54}$ H. Gambhir, The Virtual Caliphate: ISIS's Information Warfare, 2016.

${ }^{55}$ Remy Mahzam, "Rumiyah-Jihadist Propaganda \& Information Warfare in Cyberspace", Counter Terrorist Trends and Analyses 9.3 (2017): 8-14.

${ }^{56}$ Luna Shamieh and Zoltán Szenes, "The Propaganda of ISIS/DAESH through the Virtual Space", Defence against Terrorism Review 7.1 (2015).

${ }^{57}$ Sari, "Media Literasi dalam Kontra Propaganda Radikalisme dan Terorisme melalui Media Internet".

${ }^{58}$ Sari, "Media Literasi dalam Kontra Propaganda Radikalisme dan Terorisme Melalui Media Internet".Data ini juga diperoleh Sari di BNPT Tahun 2016.
} 
terprovokasi oleh berita atas yang mengatasnamakan agama. ${ }^{59}$ Keterlibatan perempuan Indonesia dalam jaringan ISIS di antaranya kelompok Mujahidin Indonesia Timur di bawah pimpinan Santoso. ${ }^{60}$

Melalui internet, ISIS telah membuktikan kemampuan mereka untuk mempropaganda Warga Negara Indonesia untuk bergabung bersama mereka.Warga Negara Indonesia telah mendukung $4 \%$ (setelah Malaysia) kepada ISIS. Berdasarkan data BNPT tahun 2017-2019, Indonesia telah menerima deportan ISIS dan lebih dari 400 deportan yang direhabilitasi oleh BNPT di Panti Sosial Marsudi Putra Handayani Jakarta (Perempuan dan Anak) dan di Rumah Perlindungan Trauma Center (Dewasa) Bambu Apus, Jakarta Timur untuk dikembalikan ke keluarga mereka. Namun 3 dari deportan tersebut ditangkap karena terlibat dalam aksi terorisme setelah dipulangkan. Indonesia juga telah memulangkan 18 retunees dimana 3 di antaranya ditahan di Mako Brimob, sementara 15 orang lainnya direhabilitasi di BNPT untuk selanjutnya dipulangkan. ${ }^{61}$

Fenomena ketertarikan masyarakat terhadap ajakan untuk melakukan aksi terorisme di media sosial ini dipengaruhi oleh pemahaman ideologi yang bertentangan dengan ideologi Pancasila. Berdasarkan survey dari lembaga Alvara Researh Center dan Mata Air Foundation ditemukan data yang menunjukkan bahwa $23 \%$ mahasiswa setuju dengan tegaknya negara Islam atau Khilafah, 23,1 \% pelajar SMA yang setuju dengan jihad untuk tegaknya negara Islam khilafah, 18, $1 \%$ pegawai swasta menyatakan tidak setuju dengan ideologi Pancasila, 19,4 \% PNS tidak setuju dengan ideologi Pancasila, 6,7\% pegawai BUMN tidak setuju dengan ideologi Pancasila, dan o,1 \% terindikasi tidak setuju dengan Pancasila. ${ }^{62}$

Di antara penyebab ketidaksetujuan terhadap ideologi Pancasila ini adalah upaya propaganda yang dilakukan oleh kelompok radikal melalui online. Dari data yang dihimpun oleh Kementerian Komunikasi dan Informatika (Kemenkominfo) hingga 26 Juni 2018 sudah ditemukan konten propaganda sejumlah 5526 yang mengarah kepada paham radikal di beberapa media sosial. Beberapa temuan di antaranya melalui Situs/Forum/File Sharing sejumlah 614, Instagram dan Facebook sejumlah 2986, Google Drive dan You Tube sejumlah 552, Telegram 502, dan Twitter sejumlah $872 .{ }^{63}$

\section{Pengaruh Media Sosial terhadap Psikologis Calon Teroris di Indonesia}

Memahami psikologi teroris bisa diartikan sebagai upaya untuk menelusuri permasalahan pada diri orang yang mencari perlindungan hak asasi manusia, menuntut kesejahteraan, dan mencari kebahagiaan. Reaksi dari ketidakpuasan teroris ini diwujudkan, salah satunya, dengan menggunggah berbagai buku, kaset, vidio, dan majalah yang mengandung konten propaganda di situs-situs, blog dan media sosial untuk disebarluaskan secara massif tanpa batas (borderless).

Saat ini media sosial (Facebook, Twitter, Instagram, WhatsApp, dan sebagainya) menjadi sarana yang efektif untuk menyebarkan berbagai informasi di seluruh belahan dunia dalam hitungan detik.Konten informasi yang disampaikan melalui media sosial mengandung sisi positif dan negatif sehingga mempengaruhi psikologi pengguna media sosial.Dengan menyadari adanya pengaruhi psikologis pengguna media sosial, kelompok ekstrimis memanfaatkannya untuk merekrut para calon angotanya.Dalam beberapa literatur terorisme yang ditulis oleh sarjana politik, dijelaskan bahwa internet

\footnotetext{
${ }^{59}$ Musdah Mulia, "Perempuan dalam Gerakan Terorisme di Indonesia", AL-WARDAH 12.1 (2019): 80-95.

${ }^{60}$ Nesa Wilda Musfia, Tri Cahyo Utomo, dan Fendy Eko Wahyudi. "Peran Perempuan dalam Jaringan Terorisme ISIS di Indonesia", Journal of International Relations 3.4 (2017): 174-180.

${ }^{61}$ Putri dan Wahyudi, "Cyber Terrorism: Strategi Propaganda dan Rekrutmen ISIS di Internet dan Dampaknya bagi Indonesia Tahun 2014-2019: 828; Nurul, R. WNI Simpatisan ISIS Kembali, Tanggung Jawab Siapa? Dalam https://www.ruangobrol.id/ 2019/07/11/fenomena/ indonesia/wni-simpatisan-isiskembali-tanggung- jawab -siapa/ Diakses pada 2 Juli 2019.

${ }^{62}$ Sadarusalam dan Hasan, "Kontra Propaganda Badan Nasional Penanggulangan Terorisme dalam Menanggulangi Perkembangan Radikalisme di Indonesia", 75.

${ }^{63}$ Sadarusalam dan Hasan, "Kontra Propaganda Badan Nasional Penanggulangan Terorisme dalam Menanggulangi Perkembangan Radikalisme di Indonesia", 75.
} 
dan media sosial bisa berfungsi sebagai suatu ruang gema (echo room) dan berperan penting dalam merekrut anggota kelompok ekstrimis. ${ }^{64}$

Para pelaku teroris sengaja melakukan propaganda ideologi-ideologi kekerasan, pendirian negara Islam, ujaran kebencian, dan hujatan terhadap produk Barat di media sosial, akun di media sosial, portal online, dan penerbitan-penerbitan berbasis Islam. ${ }^{65}$ Propaganda seperti ini dilakukan agar psikologi orang yang mendukung gerakan terorisme dapat terpengaruh.

Media sosial tidak dapat dipungkiri menjadi sarana yang sangat baik bagi kelompok teroris untuk menyebarluaskan ajaran dan ideologinya karena berlindung di balik demokrasi. Sebelum berkembang pesatnya media daring ini, proses perekrutan membutuhkan waktu lima hingga to tahun, tetapi saat ini hanya membutuhkan waktu satu tahun. ${ }^{66}$

Salah satu tokoh teroris dari Poso, Santoso alias Abu Wardah pernah memanfaatkan You Tube dengan durasi 9 menit 34 detik, yang kontennya berisi ancaman akan meledakkan Polda Metro Jaya dan mengibarkan bendera IS di Istana Merdeka. Tanyangan ini beredar luas di media sosial.Pada video ini terlihat kibaran bendera ISIS di bagian kiri gambar dan sosok seorang pria yang diduga kelompok Mujahidin Indonesia Timur, Santoso alias Abu Wardah pidato dengan semangat membara. ${ }^{67}$

Seruan melakukan aksi terorisme juga berasal dari kelompok-kelompok salafi di Timur Tengah untuk Indonesia melalui internet.Media internet ini diyakini cukup efektif karena menawarkan kesempatan untuk menciptakan identitas Islam yang generik atau de-culturated.Situs-situsnya pun beragam, seperti www.salafi.net atau www.salafipublications.com. Internet menawarkan fasilitas kepada calon teroris atau teroris untuk berhubungan langsung dengan ulama salafi lain di luar negeri, kemudian menggunakan ide atau pikiran yang mereka unduh untuk menentang tradisi lokal Islam Indonesia, dengan menolak (bypass) sumber-sumber keagamaan lokal. ${ }^{68}$

Kelompok ekstrimis atau teroris menyadari bahwa remaja mengalami fase atau masa transisi, seperti yang dikemukakan Quintan Wiktorowics (2004) sebagai cognitive opening (pembukaan kognitif). ${ }^{69}$ Cognitinive opening adalah sebuah proses mikro-sosiologis yang mendekatkan mereka pada penerimaan terhadap gagasan baru yang lebih radikal. ${ }^{\circ}$ Dengan kata lain, jika seseorang tidak memiliki pemikiran terbuka terhadap ide-ide baru, tidak kritis terhadap pesan gerakan, dan menolak pesan gerakan, maka ia meyakini ajakan ini dan bergabung dengan kelompok radikal, sehingga pada akhirnya melakukan tindakan kekerasan. Dalam psikologi sosial, kekerasan bisa mengarah pada tindakan-tindakan agresi, seperti perilaku yang membahayakan (apakah sekedar coba-coba atau benar-benar dilakukan). ${ }^{11}$

\footnotetext{
${ }^{64}$ A.Awan, A. Hoskins, dan B O'Loughlin Radicalisation and the Media: Connectivity and Terrorism in the New Media Ecology (New York: Routledge, 2011).

${ }^{65}$ Nafi' Muthohirin, Radikalisme Islam dan Pergerakannya di Media Sosial, Jurnal Ilmu-Ilmu Keislaman Afakruna, Vol. 11 No. 2 (Desember 2015): 241.

${ }^{66}$ Poltak Partogi Nainggolan, dkk, Kerja Sama Internasional Melawan Terorisme (Jakarta: Yayasan Pustaka Obor Indonesia, 2019), 127.

${ }^{67}$ Prayitno Ramelan, Ancaman Virus Terorisme: Jejak Teror di Dunia dan Indonesia (Jakarta: PT. Gramedia, 2017),

64.

${ }^{68}$ Anthony Bubalo and Greg Fealy, Joining the Caravan? The middle East, Islamism, and Indonesia (Australia: The Low Institute for International Policy, 2005), 63-64.

${ }^{69}$ Dalam analisa Quintan Wiktorowics, ada empat faktor yang berpotensi bagi orang yang bergabung dengan kelompok Islam radikal, yaitu: 1. Cognitive opening, yaitu seseorang menerima kemungkinan ide-ide dan pandanganpandangan baru 2. Religious seeking, yaitu seseorang mencari makna melalui ungkapan agama 3.Frame alignment, yaitu perwakilan publik yang diusungkan oleh kelompok radikal dan bahkan dibujuk untuk berpartisipasi 4. Socialization, yaitu pengalaman selama belajar dan aktivitas keagamaan seseorang digunakan untuk memfasilitasi indoktrinasi, membangun identitas, dan merubah nilai.Quintan Wiktorowicz, "Joining the Cause: Al-Muhajiroun and Radical Islam", The Roots of Radical Islam (2004).

${ }^{70}$ Terorisme, Badan Nasional Penanggulangan, "Strategi Menghadapi Paham Radikalisme Terorisme-ISIS", Jakarta: Belmawa (2016).

${ }^{71}$ J.J. Allen and C.A. Anderson, "Aggression and Violence: Definitions and Distinctions" in P. Sturmey, ed., The Wiley Handbook of Aggression and Violence (New York: Wiley, 2017).
} 
Dengan alasan seperti ini, secara psikologis remaja sangat mudah terpengaruh oleh bujukan kelompok radikal dan terorisme.Kelompok teroris mengincar orang-orang yang merasa kecewa, tidak puas, frustasi, dan mudah marah terhadap kondisi sosial dan pemerintah.Kelompok teroris menyediakan fasilitas dan perlengkapan kepada para remaja yang menginginkan kegagahan dan kelancaran agresinya.

Data yang telah berhasil dihimpun oleh BNPT, ada beberapa kasus yang menunjukkan pengaruh media internet terhadap pembentukan pemikiran radikal sesorang hingga melakukan aksi terorisme. Berikut kasus-kasusnya:

Tabel 1

Pengaruh Media Online terhadap Pembentukan Tindakan Radikal

\begin{tabular}{|c|c|c|}
\hline No & Nama & Kasus \\
\hline 1 & $\begin{array}{l}\text { Agus Aston } \\
\text { Figian alias } \\
\text { Toriq alias } \\
\text { Abu } \\
\text { Zulfikar }\end{array}$ & $\begin{array}{l}\text { Termasuk dalam kelompok Abu Hasymy (Abu Hanifah). } \\
\text { Berencana melakukan pemboman di wilayah Freefort dan } \\
\text { Kedubes AS Surabaya. Ia mengaku menjadi radikal karena } \\
\text { terpengaruh dengan banyak membaca berita dan kajian-kajian } \\
\text { dari www.arrahmah.com. Selain itu, Agus Aston banyak } \\
\text { mempelajari bagaimana cara merakit bom dari media internet } \\
\text { radikal lainnya. }\end{array}$ \\
\hline 2 & $\begin{array}{l}\text { Lima } \\
\text { remaja SMK } \\
\text { Klaten }\end{array}$ & Mengaku belajar merakit bom dari website forum al-busyro \\
\hline 3 & $\begin{array}{l}\text { Ahmad } \\
\text { Taufiq alias } \\
\text { Ofi }\end{array}$ & $\begin{array}{l}\text { Kelompok gerakan radikal Thoifah Mansyiah (Kataib-al-Iman). } \\
\text { Ia menjadi tersangka dalam bom Myanmar setelah lama tidak } \\
\text { menghadiri pengajian. Ia mengaku mendownload pengajian } \\
\text { dalam bentuk } \mathrm{MP}_{3} \text { yang berpaham radikal dari website radikal. }\end{array}$ \\
\hline 4 & $\begin{array}{l}\text { Ahmad } \\
\text { Azhar } \\
\text { Basyir }\end{array}$ & $\begin{array}{l}\text { Ia mengaku banyak mencari artikel di internet tentang } \\
\text { bagaimana cara membuat detonator, hingga pada akhirnya ia } \\
\text { menemukan salah satu akun Facebook Salafi-Jihady yang } \\
\text { membahas tentang hal tersebut. }\end{array}$ \\
\hline 5 & $\begin{array}{l}\text { Judi } \\
\text { Novaldi bin } \\
\text { Mulyadi }\end{array}$ & $\begin{array}{l}\text { Ia merupakan pemuda yang berasal dari Jambi, mengancam } \\
\text { ayahnya (47) dan menyendera adiknya Maulana (6). Polisi } \\
\text { menemukan } 4 \text { bendera hitam yang bertuliskan Bahasa Arab } \\
\text { yang biasa digunakan ISIS, } 1 \text { sweater loreng warna hitam } \\
\text { bertuliskan Bahasa Arab serupa dengan identitas ISIS, } 1 \text { stel } \\
\text { pakaian loreng dan kaos loreng, dan } 1 \text { surban berwarna merah } \\
\text { dan hitam yang bertuliskan Bahasa Arab. Judi mengaku } \\
\text { membeli atribut yang biasa digunakan ISIS melalui informasi } \\
\text { di jejaring sosial. }\end{array}$ \\
\hline 6 & $\begin{array}{l}\text { Muhammad } \\
\text { Alfian } \\
\text { Nurzi dan } \\
\text { Asyahnaz }\end{array}$ & $\begin{array}{l}\text { Muhammad Alfian Nurzi berasal dari Kalimantan dan } \\
\text { Asyahnaz berasal dari Kabupaten Bandung. Sebelum berangkat } \\
\text { ke Suriah, mereka sering menggunakan media online } \\
\text { khususnya media sosial dalam berkomunikasi dengan } \\
\text { kelompok ISIS. }\end{array}$ \\
\hline 7 & $\begin{array}{l}\text { Di Amerika } \\
\text { Serikat: } 3\end{array}$ & $\begin{array}{l}\text { Ketiga remaja ini diduga direkrut ISIS melalui media sosial. } \\
\text { Ketiga remaja ini berhasil dihentikan di Jerman pada Oktober }\end{array}$ \\
\hline
\end{tabular}


Sustainable, Vol. 3 No. 1, 2020, $35-52$.

\begin{tabular}{|c|l|l|}
\hline No & \multicolumn{1}{|c|}{ Nama } & \multicolumn{1}{c|}{ Kasus } \\
\hline $\begin{array}{l}\text { remaja } \\
\text { Denver }\end{array}$ & 2014 dan dikirim kembali ke Amerika Serikat. \\
\hline 8 & $\begin{array}{l}\text { Di Amerika } \\
\text { Serikat: } 3 \\
\text { remaja } \\
\text { Denver }\end{array}$ & $\begin{array}{l}\text { Ketiga remaja tersebut diduga direkrut ISIS melalui media } \\
\text { sosial. Ketiganya berhasil dihentikan di Jerman pada Oktober } \\
\text { 2014 dan dikirim kembali ke Amerika Serikat. }\end{array}$ \\
\hline
\end{tabular}

Sumber: BNPT, 2016

Langkah-Langkah Strategis dalam Mencegah Calon Teroris melalui Media Sosial di Indonesia

BNPT telah melakukan berbagai upaya untuk mencegah perekrutan calon teroris, di antaranya merumuskan, mengkoordinasikan, dan melakukan pengawasan (baik pengawasan administratif ataupun pengawan fisik) melalui media center. Pemantauan dan pengendalian terhadap propaganda terorisme dilakukan dengan melakukan koordinasi dan pengawasan: a. keluar masuknya senjata api dan bahan peledak illegal b. napi teroris, mantan napi, dan keluarganya c. keluar masuknya orang dari dank e luar Indonesia d. aliran dan yang diduga digunakan untuk mendanai kegiatan terorisme, dan peredaran bahan kimia, biologi, radio aktif, dan nuklir yang kemungkinan digunakan untuk kegiatan terorisme. ${ }^{72}$

Dalam mengatasi aksi-aksi terorisme ini, BNPT telah memanfaatkan berbagai sarana dana prasaran berupa media massa baik bersifat offline maupun online melalui Pusat Media Damai untuk menyebarluaskan wawasan perdamaian dan kebangsaan. ${ }^{73}$

Berbagai sarana prasarana berupa saluran media massa yang ada baik yang bersifat online maupun offline, telah dimanfaatkan oleh pihak BNPT melalui Pusat Media Damai untuk menyebarkan wawasan perdamaian dan kebangsaan.Selain itu, BNPT juga melakukan pencegahan aksi terorisme melalui sistem online tentang workshop bagaimana menjalankan kehidupan berbangsa dan bernegara yang benar.Melalui kegiatan ini, generasi muda diarahkan untuk melawan paham radikalisme di dunia maya. ${ }^{74}$

Upaya-upaya lain dilakukan oleh BNPTuntuk menangkal paham radikalisme dan terorisme di dunia maya, termasuk media sosial, yaitu mengadakan pelatihan-pelatihan bagi kaum muda. Anak-anak muda diarahkan agar menyampaikan pesan damai dan melawan propaganda terorisme di media sosial.Upaya seperti ini menjadi strategi yang baik karena anak-anak muda merupakan generasi penerus bangsa. Demikian juga kegiatan roadshow ke kampus-kampus diyakini BNPT sebagai cara yang tepat untuk mengajak mahasiswa menangkal paham terorisme dan radikalisme. Kegiatan seminar atau kuliah umum di kampus yang mengusung anti paham terorisme dan radikalisme dapat menjadi filter bagi mahasiswa agar tidak terlibat menjadi calon teroris atau teroris.

Bahkan sejak pendidikan anak usia dini,pesan humanis dalam pelajaran agama sudah semestinya direaktualisasikan oleh para guru. Setiap kurikulum pendidikan yang dirancang bertujuan untuk menjadikan anak didik menjadi pribadi yang lemah lembut, beradab, dan toleran terhadap orang lain.

Sebagaimana dipahami bahwa seorang teroris bukanlah dilahirkan, akan tetapi dibentuk. Jiwa seseorang yang dibentuk dengan paham radikal niscaya akanmelahirkan sikap narsisme. Sikap narsisme, jika ditinjau dari perspektif psikologis, apabila tidak digiring ke arah positif akan melahirkan sikap

${ }^{72}$ Alfrialdo Ibrahim, "Peran BNPT dalam Pencegahan dan Penanggulangan Terorisme menurut Perpres No. 46 Tahun 2010 Tentang BNPT", LEX CRIMEN 7.8 (2018).

${ }^{73}$ Bambang Wiji Asmoro Sadarusalam dan Khoirul Hasan, "Kontra Propaganda Badan Nasional Penanggulangan Terorisme dalam Menanggulangi Perkembangan Radikalisme di Indonesia", The Indonesian Journal of Politics and Policy 1.1 (2019): 74-82.

${ }^{74}$ www.damailahindonesiaku.com/ tantangan-bersama-dalam-upaya-pencegahan-paham-radikal-terorisme.html Diakses 15 Juli 2019. 
sombong, anti-sosial, dan tidak menghargai orang lain. Sikap-sikap negatif seperti ini akan lebih cepat menyentuh jiwa calon teroris apabila ditampilkan atau disiarkan melalui media sosial tentang kekerasan terhadap umat Muslim. Tentunya, upaya penanggulangan terhadap tayangan kekerasan - yang dianggap calon teroris sebagai penyikasaan terhadap umat Muslim - perlu dilakukan penjelasan dan pemahaman melalui media sosial.

Di kalangan umat beragama, upaya untuk menangkal paham terorisme dapat dilakukan dengan memberikan pemahaman dan pengamalan yang bersifat moderat (wasat \}i>yah). Moderasi beragama akan melahirkan sikap yang lebih toleran, ramah, dan meningkatkan martabat agamanya. Kadangkala tindakan terorisme ini dilakukan atas alasan keyakinan adanya perintah untuk membunuh atas kelompok nonmuslim.Untuk mengatasi pemahaman seperti ini, tokoh agama atau pemuka agama perlu mengembangkan kesadaran terhadap pesan kemanusiaan (humanisme) agama karena semua agama mengajarkan pentingnya menghargai perbedaan keyakinan. Tokoh-tokoh agama perlu terus melakukan dialog agama dan dialog peradaban pada setiap level lokal, nasional, dan global secara sistematis dan terencana.

Tokoh agama perlu menyampaikan tafsiran makna rahlmatan lil $a>l a m i>n$ secara luas. Seruan Islam rah\}matan lil $a>$ lami $>n$ ini tidak hanya disampaikan pada momen tertentu an sich (seperti hari-hari besar agama dan nasional), tetapi bisa disampaikan dalam berbagai ruang dan kesempatan. Demikian juga masyarakat perlu memahamai berbagai kajian tafsir dengan beragami pendekatan, seperti psikologi, sosiologi, antropologi, dan sebagainya.

Pencegahan dan penanggulangan pemahaman terorisme juga dilakukan dengan penguatan nasionalisme dan memfungsikan kearifan lokal di setiap wilayah dan etnis Indonesia.Tidak jarang sikap nasionalisme diabaikan oleh kelompok yang merasa kecewa terhadap sikap ketidakadilan pemerintah.Untuk mensikapi kekecewaan kelompok anti nasionalisme ini, perlu adanya upaya menciptakan pemerintahan yang berkeadilan. Selain pemerintahan yang adil, para pemimpin di semua level perlu menampilkan sikap keteladanan dalam kehidupan beragama, bermasyarakat, bernegara, dan penampilan personalnya.

Menurut Puput Agus Setiawan, sikap teroris lebih eksklusif dan tidak moderat.Untuk mengantisipasi menyebarnya paham terorisme, mahasiswa di perguruan tinggi perlu diarahkan untuk mencintai NKRI.Demikian juga kegiatan rohis di SMA/SMK/sederajat perlu diawasi agar tidak berpikir radikal.Ururutan yang paling rentan untuk diwaspadai penyebaran paham terorisme dan radikalisme, dalam analisa Puput, adalah SMA Negeri, Madrasah Aliyah Negeri, Perguruan Tinggi Keagamaan Negeri, dan Perguruan Tinggi Umum.Kelompok teroris bisa memanfaatkan media sosial untuk dijadikan sarana yang efektif dalam penyebaran pemikiran radikalisme bahkan perekrutan teroris. Melalui media sosial, kelompok radikal atau teroris bisa menerima atau mengirim pesan di setiap saat dan setiap tempat.Dalam keyakinan teroris, orang yang belum sepaham dengan mereka dianggap kafir, dan Indonesia masih dalam dikategorikan wilayah da>rul harbi (kawasan perang).Puput juga menjelaskan bahwa kearifan lokal Indonesia masih mampu menjadi daya tangkal dan pencegahan penyebaran radikalisme trorisme di Indonesia. ${ }^{75}$

Memang saat ini media online menjadi kebutuhan setiap orang dalam berbagai kepentingan, tanpa terkecuali penyebaran informasi agama yang bernuansa radikal.Kelompok radikal-terorisme memiliki pemahaman teknologi canggih.Untuk menangani penyebaran dan perekrutan terorisme melalui media sosial, aparat perlu dibekali kemampuan deteksi yang lebih canggih dan dinamis terhadap ancaman melalui media sosial.

${ }^{75}$ Wawancara dengan Puput Agus Setiawan, Kasi Penelitian dan Evaluasi Badan Nasional Penanggulangan Terorisme), Citereup Bogor Jawa Barat, 6 Juli 2019. 
Bagaimana dengan gerakan teorisme di Bangka Belitung? Subardi, selaku Pengurus Bidang Penelitian dan Pengkajian Forum Koordinasi Pencegahan Terorisme (FKPT) Provinsi Kepulauan Bangka Belitung menjelaskan seputar terorisme di Bangka Belitung bahwa gejala teroris di Bangka Belitung belum ada, termasuk sel-sel teroris di provinsi ini belum ditemukan. Sebagai perpanjangan tangan dari BNPT Pusat,hanya bertugas sebagai pencegahan aksi teroris.Menurut Subardi, sikap radikalisme di Bangka Belitung masih sebatas pemikiran, bukan aksi radikalisme.Mengenai media sosial, dalam analisa Subardi, menjadi ruang untuk menggiring masyarakat bersikap radikalisme dan pada kahirnya orang yang terpengaruh sikap radikalisme ini bisa menjadi teoris.Sikap radikalisme di Bangka Belitung masih bisa dibendung oleh kuatnya budaya melayu Bangka Belitung.Adapun indikasi pemikiran radikalisme di Bangka Belitung lebih disebabkan oleh kekecewaan ketimpangan ekonomi dan politik secara nasional.Sedangkan sikap dan pemikiran radikal di kalangan tokoh agama dan tokoh masyarakat belum mencuat.Tokoh agama dan tokoh masyarakat masih meyakini bahwa Bangka Belitung masih aman dari terorisme. ${ }^{6}$

\section{Kesimpulan}

Perekrutan terorisme melalui media sosial di Indonesia dilakukan oleh kelompok teroris bertujuan agar calon teroris menaruh rasa simpati atas tayangan penindasan umat Muslim, yang menurut mereka perlu dibantu atas nama jihad. Adapun pemicu (trigger) aksi teroris adalah aspek politik, ekonomi, sosial (kelompok), dan agama.Apapun alasannya, aksi terorisme tidak dibenarkan oleh agama dan negara.

Langkah-langkah pencegahan perekrutan teroris melalui media sosial adalah pembinaan kepada masyarakat tentang bahaya terorisme oleh pemerintah (Kenterian Komunikasi dan Informasi Republik Indonesia), tokoh agama, dan tokoh masyarakat.

\section{DAFTAR PUSTAKA}

Abas, Nasir.Membongkar Jamaah Islamiyah: Pengakuan Mantan Anggota JI. Jakarta: Grafindo Khazanah Ilmu, 2005.

Ali-Fauzi, Ihsan dan Solahudin. Deradikalisasi di Indonesia dalam Ihsan Ali-Fauzi, dkk (Editor),Kebebasan, Toleransi dan Terorisme: Riset dan Kebijakan Agama. Jakarta: Pusat Studi Agama dan Demokrasi, 2017.

Allen, J.J. and Anderson, C.A. "Aggression and Violence: Definitions and Distinctions" in P. Sturmey, ed., The Wiley Handbook of Aggression and Violence. New York: Wiley, 2017.

Awan, A., Hoskins, A. dan O'Loughlin, B. Radicalisation and the Media: Connectivity and Terrorism in the New Media Ecology. New York: Routledge, 2011.

Bin Ali, Mohamed. The Roots of Religious Extremism: Understanding the Salafi Doctrine of Al-Wala' Wal Bara'. London: Imperial College Press, 2016.

Blakeley, R. State Terrorism in the Social Sciences: Theories, Methods, and Concept in R. Jackson, E Mutphy and S. Poynting (eds.). Contemporary State Terrorism: Theory and Practice. London: Routledge, 2009.

${ }^{76}$ Wawancara dengan Subardi, Pengurus Bidang Penelitian dan Pengkajian Forum Koordinasi Pencegahan Terorisme (FKPT) Provinsi Kepulauan Bangka Belitung, Pangkalpinang, 8Agustus 2019. 
Bohleber, Werner. "Collective Phantasms, Destructiveness, and Terrorism" in Svere Varvin and Vamik D. Volkan (eds.). Violence or Dialogue?Psychoanalytic Insight on Terror and Terrorism. London: Routledge, 2018.

Bubalo, Anthony and Fealy, Greg.Joining the Caravan? The middle East, Islamism, and Indonesia. Australia: The Low Institute for International Policy, 2005.

Carlisle, Rodney P., ed. One Day in History: September 11, 2001. New York: HarperCollins, 2007.

Gertz, Bill. "New Al Qaeda Group Produces Recruitment Material for Americans, Westerners". The Washington Free Beacon, 2014.

Golose, Petrus Reinhar. Invasi Terorisme ke Cyberspace. Jakarta: Yayasan Pengembangan Kajian Ilmu Kepolisian, 2015.

Hassan, Muhammad Haniff. Civil Disobedience in Islam: A Contemporary Debate. Singapore: Palgrave Macmillan, 2017.

Pray to Kill. Jakarta: Grafindo, 2006.

Hudson, Rex. The Sociology and Psychology of Terrorism: Who Becomes a Terrorist and Why?. New York: Skyhorse Publishing, 2018.

Hwang, Julie Chernov. Why Terrorists Quit: The Disengagement of Indonesian Jihadists. Ithaca and London: Cornell University Press, 2018.

Ibrahim, Alfrialdo. "Peran BNPT dalam Pencegahan dan Penanggulangan Terorisme menurut Perpres No. 46 Tahun 2010 Tentang BNPT". LEX CRIMEN 7.8 (2018).

Karnavian, Muhammad Tito.Explaining Islamist Insurgencies: the Case of al-Jamaah al-Islamiyyah and the Radicalisation of the Poso Conflict, 2000-2007. London: Imperial College Press, 2015.

Kraft, Michael B. "Evolution of U.S. Counterterrorism Laws, Policies, and Programs", in Evolution of U.S.Counterterrorism Policy, Yonah Alexander and Michael B. Kraft. London: Praeger Security International, 2008.

Nainggolan, Poltak Partogi, dkk. Kerja Sama Internasional Melawan Terorisme. Jakarta: Yayasan Pustaka Obor Indonesia, 2019.

Nassar, J. Globalization and Terrorism: The Migration of Dreams and Nightmares. Lanham: Rowman \& Littlefield, 2005.

Newman, Graeme and Clarke, Ronald V. Terrorism in Mangai Natarajan, ed.,International and Transnational Crime and Justice. New York: Cambridge University Press 2019.

Perimutter, Dawn. Investigating Religious Terrorism and Ritual Crimes. Boca Raton, London, New York, and Washington, D.C.: CRC Press, 2004.

R. Nurul. WNI Simpatisan ISIS Kembali, Tanggung Jawab Siapa? Dalam

Ramelan, Prayitno.Ancaman Virus Terorisme: Jejak Teror di Dunia dan Indonesia. Jakarta: PT. Gramedia, 2017.

Setia, Putu. $\quad$ Mendebat Bali: Catatan Perjalanan Budaya Bali hingga Bom Kuta. Denpasar: PT Pustaka Manikgeni, 2012.

Silke, Andrew. State Terrorism in Andrew Silke (ed.). Rourledge Handbook of Terrorism and Counterrorism. New York: Routledge, 2019.

Silke, Andrew. The Study of Terrorism and Counterterrorism. London/New York: Routledge, 2019.

Terorisme, Badan Nasional Penanggulangan, "Strategi Menghadapi Paham Radikalisme TerorismeISIS", Jakarta: Belmawa, 2016

Townshend, Charles. Terrorism: A Very Short Introduction. Oxford and New York: Oxford University Press, 2018.

United Nations Office on Drug and Crime, 2012, 3.

Weinberg, Leonard and Eubank, William L.What Is Terrorism?. New York: Chelsea Publishing, 2006.

Wiktorowicz, Quintan. "Joining the Cause: Al-Muhajiroun and Radical Islam". The Roots of Radical Islam (2004).

Wilkinson, P. International Terrorism New Risks to World Order in J. Balylis and N. Rengger (eds.). Dilemmas of World Politics International Issues in a Changing World. London: Clarenden Press, 1992. 
Christensen, Dag Arne and Aars, Jacob. "Does Democracy Decrease Fear of Terrorism?" Terrorism and Political Violence 31.3 (2019): 615-631.

D, Lewis. "Crime, terror and the state in Central Asia".Global Crime, 15 (2014): 337

Dawson, Lorne L. "Challenging the Curious Erasure of Religion from the Study of Religious Terrorism". Numen, 65.2-3 (2018): 141-164.

"Debating the Role of Religion in the Motivation of Religious Terrorism".Nordic Journal of Religion and Society, 31.02 (2018): 98-117.

Ejeh, E. U., Bappah, A. I., and Dankofa, Yusuf. "Nature of Terrorism and Anti-Terrorism Laws in Nigeria". Nnamdi Azikiwe University Journal of International Law and Jurisprudence, 10.2 (2019): 186-192.

Ezeldin, A. Terrorism and political violence: An Egyptian Perspective. Chicago: Office of International Criminal Justice, University of Illinois 1987.

Falk, Ofir. "Terrorism: Agreeing on the Basics". American Diplomacy (2019): 1-7.

Galamas, Francisco. "Terrorism in Indonesia: An Overview". Research Papers 4 (2015): 10.

Hoffman, Aaron M. and Shelby, William."When the "Laws of Fear" Do Not Apply: Effective Counterterrorism and the Sense of Security from Terrorism”.Political Research Quarterly, Vol. 70, 3, (2017): 618-631.

Ken, Miichi. "Looking at Links and Nodes: How Jihadists in Indonesia Survived". Southeast Asian Studies, Vol. 5, No. 1 (April 2016): 139.

Kydd, A. H. and B. F., Walter. “The Strategies of Terrorism,” International Organization, 31, 1 (2006): 49-80.

Lil-Malayin, J. A New Collocation Extraction Method: Combining Multiple Association Measures. Proceedings of the Seventh International Conference on Machine Learning and Cybermetrics, Kumming (2007): 12-15.

Mahzam, Remy."Rumiyah-Jihadist Propaganda \& Information Warfare in Cyberspace". Counter Terrorist Trends and Analyses 9.3 (2017): 8-14.

Muhammad Haniff Hassan, Pray to Kill (Jakarta: Grafindo, 2006), 28; Yoyo Hambali, "Hukum Bom Bunuh Diri Menurut Islam Radikal dan Islam Moderat”, Maslahah, Vol.1, No. 1, Juli 2010, 52.

Mulia, Musdah. "Perempuan dalam Gerakan Terorisme di Indonesia". AL-WARDAH 12.1 (2019): 80-95.

Musfia, Nesa Wilda, Utomo, Tri Cahyo dan Wahyudi, Fendy Eko. "Peran Perempuan dalam Jaringan Terorisme ISIS di Indonesia". Journal of International Relations 3.4 (2017): 174-180.

Muthohirin, Nafi'. Radikalisme Islam dan Pergerakannya di Media Sosial, Jurnal Ilmu-Ilmu Keislaman Afakruna, Vol. 11 No. 2 (Desember 2015): 24-259.

Ochu, Michael Chimaobi and Otlogetswe, Thapelo J. "The Study of Terror, Terrorise, Terrorism, Terrorist in Two Nigerian Newspapers", Marang: Journal of Language and Literature 30 (2018).

Putri, Santi Dwi dan Wahyudi, Fendy Eko. "Cyber Terrorism: Strategi Propaganda dan Rekrutmen ISIS di Internet dan Dampaknya bagi Indonesia Tahun 2014-2019". Journal of International Relations 5.4 (2019): 827-833.

Sadarusalam, Bambang Wiji Asmoro dan Hasan, Khoirul."Kontra Propaganda Badan Nasional Penanggulangan Terorisme dalam Menanggulangi Perkembangan Radikalisme di Indonesia". The Indonesian Journal of Politics and Policy 1.1 (2019): 74-82.

Sari, Benedicta Dian Ariska Candra."Media Literasi dalam Kontra Propaganda Radikalisme dan Terorisme melalui Media Internet". Peperangan Asimetrik 3.1 (2017).

Durr, Brenna. "ISIS: The Use of Social Media”. Thesis, The Faculty of Utica College, 2016.

Bellandi, Rose. "Terrorist Ideology and Behavior: An Examination of the Behavior of Known and Unknown Perpetrators". Dissertation, School of Criminal Justice, The University at Albany, State University of New York, 2016.

Milla, Mirra Noor. "Dinamika Psikologis Perilaku Terorisme: Identitas dan Pengambilan Keputusan Jihad di Luar Wilayah Konflik pada Terpidana Kasus Bom Bali Di Indonesia”. Disertasi, Universitas Gajah Mada, 2009.

Rivera, Rafael Edmundo Linera. "Social Representations of Threat in Extended Media Ecology: Sochi 2014 Olympics, Jihadist Deeds, and Online Propaganda”. Dissertation, Fielding Graduate University, Santa Barbara, California, 2016. 
Saiya, Nilay. The Roots of Religious Terrorism.Dissertation, Graduate Program in Political Science Notre Dame, Indiana, 2013.

Shor, Eran. "Terrorism and Counterterrorism: A Comparative Cross-National Analysis". Dissertation, Sociology Stony Brook University, 2010.

"Indonesia Social Media Slams Use of Children in Church Bombings", BBC Monitoring Asia Pacific, London, 14 May 2018.

"Indonesia: Indonesia will not Flinch in War against Terrorism - Jokowi", Asia News Monitor, Bangkok, 14 May 2018. Deadly Terrorist Attack on Indonesia Police Headquarters, Iran Daily; Tehran, 16 May 2018.

Gambhir, H.The Virtual Caliphate: ISIS's Information Warfare, 2016.

Setia, Putu. "Mariot II", dalam, Cari Angin 2: Kumpulan Esai di Koran Tempo Minggu 2009-2012, Putu Setia dan Toriq Hadad. Jakarta: TEMPO Publishing, 2013.

Shamieh, Luna and Zoltán Szenes."The Propaganda of ISIS/DAESH through the Virtual Space". Defence against Terrorism Review 7.1 (2015).

Widiatno, Andi. "Tinjauan Yuridis Penanggulangan Tindak Pidana Terorisme dalam Menyebarkan Propaganda Melalui Media Sosial". Hukum Pidana dan Pembangunan Hukum 1.1 (2018).

Wilson, Emma. "Combatting Organised Crime and Terrorism in Central Asia," (2018).

Young, Joseph K. "Measuring Terrorism," Terrorism and Political Violence, 31.2 (2019): 323-345.

Wawancara dengan Puput Agus Setiawan, Kasi Penelitian dan Evaluasi Badan Nasional Penanggulangan Terorisme), Citereup Bogor Jawa Barat, 6 Juli 2019.

Wawancara dengan Subardi, Pengurus Bidang Penelitian dan Pengkajian Forum Koordinasi Pencegahan Terorisme (FKPT) Provinsi Kepulauan Bangka Belitung, Pangkalpinang, 8Agustus 2019.

www.damailahindonesiaku.com/ tantangan-bersama-dalam-upaya-pencegahan-paham-radikalterorisme.html Diakses 15 Juli 2019.

https://www.ruangobrol.id/ 2019/o7/11/fenomena/ indonesia/wni-simpatisan-isiskembali-tanggung- jawab -siapa/ Diakses pada 2 Juli 2019. 